\title{
KERKLIKE STANDPUNTE TEN OPSIGTE VAN TREKARBEID
}

\section{Probleemstelling}

Trekarbeid kom oral in die wêreld voor waar 'n ontwikkelde land arbeid vir sy ekonomie van 'n onontwikkelde land kan bekom. Die moontlikhede in die ontwikkelde land „trek" veral ongeskoolde arbeid uit die onontwikkelde lande. Die verdienste in lone kompenseer skynbaar genoegsaam vir die ongerief en selfs ontbering wat dit meebring.

Kerklike standpunte oor trekarbeid is van heel resente datum en begelei die na-oorlogse ideologiese stryd.

In Woord en Daad van Julie 1975 skryf prof. J. H. Coetzee oor Suid-Afrika se Volkerebeleid onder die opskrif: „'n Hedendaagse Uitlandervraagstuk". Hy wys daarop dat die toenemende swart werkersgetalle en gevolglike magspotensiaal „... het onweerstaanbaar gelei tot 'n aantal verreikende eise waaronder afskaffing van instromingsbeheer, opheffing van die trekarbeidstelsel, gelyke beloning, beter behuising, reg op vaste eiendom, bedingingsmag deur middel van geregistreerde vakunies en deelname in sosiaal-kulturele en ontspanningsfasiliteite. Hierdie eisende stemme word steeds duideliker en dringender en het ook die steun van die tuislandleiers". Hy vervolg: „Toekomstige beleid sal hier fyn moet onderskei tussen onregverdig. bare diskriminasie en verantwoorde differensiasie..." Trekarbeid en instromingsbeheer moet moreel verantwoord wees.

„In sake rakende instromingsbeheer en trekarbeid as stelsels word die onderskeid tussen diskriminasie en differensiasie minder duidelik en die saak veel ingewikkelder. Die implikasie met betrekking tot behuising en dienste in die geval van onbeheerde arbeidstoevloei en gesinstrekarbeid is onoorsienbaar. Die politieke implikasies sny na weerskante. $\mathrm{Na}$ die swart kant hou dit die leegloop van die tuislande in en dat die hele bodem uit die beleid geslaan word. Al wat sal oorbly, is regerings met staatsgrense maar sonder onderdane of dan wel met onderdane woonagtig buite die kring van hulle jurisdiksie. Na die blanke kant behels dit die toename in die nadelige getalleverhouding tussen swart en blank en 'n voortgesette en steeds intensiewer druk d.m.v. arbeidsonluste, stedelike terreur, buitelandse politieke, ekonomiese en selfs militêre optrede."

Trekarbeid ontwrig die trekarbeider, sy gesin en tuisland en konfronteer Suid-Afrika met 'n nuwe „uitlander"-vraagstuk. Die SuidAfrikaanse Republiek het eenmaal onder 'n ,uitlander-vraagstuk" ondergegaan. Vyandelike organisasies het vandag trekarbeid in hulle „program" opgeneem en ontplooi 'n definitiewe patroon in hulle aanslag teen die beleid van veelvolkige ontwikkeling.

Suid-Afrika het reeds kostelike tyd verloor. Prof. Coetzee sê: „Uit vrees vir beskuldigings van neo-kolonialisme gekoppel aan selfsug en gebrek aan begrip van die omvang en dringendheid van die situasie, het ons ' $n$ kwarteeu verspeel vir sover dit 'n radikale en planmatige ontwikkeling as konsolidasie van die tuislande betref gepaard met die nodige ekonomiese desentralisasie of nuwe ekono- 
miese ewewig, die skepping van arbeids- en beleggingsmoontlikhede en die industrialisering van die lande. Hoe langer hiermee getalm en klein politiek gespeel word, des te geringer word die reeds geringe moontlikhede om 'n toekoms van politieke onderhorigheid van die blanke nasie aan ' $n$ swart meerderheidsregering af te weer.'

\section{Die trekarbeider}

Trekarbeid kom lank reeds in die wêreld en in Suid-Afrika voor. In teorie het die staat alle Bantoes in blanke gebiede en kerke slegs die korttermynarbeider as trekarbeider beskou. ${ }^{2}$ Ander aanvaar die geografiese grense van die eertydse Britse Dominion Suid-Afrika as uitgangspunt en dan kom die enigste trekarbeiders uit Lesotho, Botswana, Malawië ens. Werkers uit die tuislande mag dan nie as trekarbeid beskou word nie.

Adjunk-Minister Koornhof het in 1971 gevra dat liefs van kontrakarbeid eerder as van trekarbeid gepraat moet word. Kontrakarbeiders kan in die kategorië van immigrant, migrasiewerker en grenswerker (reisende werker) onderskei word. Onder "trekarbeider" moet dus „migrasiewerker" verstaan word. ${ }^{3}$

'n Trekarbeider is ' $n$ persoon wat sonder sy familie tydelik in stad, dorp of plaas verkeer ter wille van en slegs met die oog op sy werk. Iemand hou op om 'n trekarbeider te wees wanneer hy nie meer die "trek" van sy tuisgebied of plattelandse huis voel nie." Die trekarbeider kan dus geleidelik in dorpsgebiede immigrant word. Tans het reeds ongeveer 5 miljoen Bantoes en 3,25 miljoen blankes verstedelik. Blanke verstedeliking is feitlik versadig, terwyl die Bantoe nog 'n potensiaal van 260 persent tot verstedeliking besit.

In Suid-Afrika verkeer enigiets tot 1 miljoen vreemde Bantoe van buite Suid-Afrika as trekarbeiders onder kontrakte van ongeveer 12 maande. Dit is meestal mans tussen 20 en 35 jaar, wat hulleself ook inderdaad as tydelike besoekers beskou en dus ook nie kerklik ingeskakel wil word of meeleef nie. ${ }^{5}$ Van die 247000 inheemse Bantoe trekarbeiders is die grootste massa ongetroud. „The migrant labourer belongs, as far as his person and his background is concerned, to his homeland but as labourer, he belongs to an urban area which is possibly foreign to him". 0

\section{Oorsake van trekarbeid}

Daar heers redelik eenstemmigheid dat armoede en geldnood in die tuis-ekonomie die vernaamste oorsaak vir trekarbeid is. ${ }^{7}$ „Die Bantoe se trek na die stede word primèr ekonomies gedetermineer, en sy terugkeer na die tuislande sal slegs teweeg gebring kan word deur ekonomiese ,trek"-faktore in laasgenoemde gebiede te skep wat minstens net so sterk is as die "trek"-faktore in Blanke gebiede".8 Juis die ekonomiese oorsaak gee in die woorde van prof. N. Manganyi aanstoot want „ekonomic life must remain a servant to man (humanisation) rather than the international cancer that it has become Juring our time (dehumanisation)".9

Trekarbeid word egter ook veroorsaak deur 'n tradisionele nomadiese "wanderlust". Daarom eis sommige volke dat jong manne 
eers moes ,gejoin" het, voordat hulle volwasse beskou word. Avontuur en prestige, verhoging van lewensstandaard, lewensonderhoud vir ,afgetrede" ouers, lobola, akkulturasie in 'n nuwe vryer Westerse lewenswyse teenoor die sosiale en religieuse tradisie dra almal by tot trekarbeid. Die Bantoe sien trekarbeid anders as die Blanke.

Uit 'n totaal ander hoek skryf dr. Francis Wilson trekarbeid toe aan die beleid van afsonderlike ontwikkeling en sê „either the goal of separate development has to be abandoned or the country has to accept the fact the economy is not going to grow"." Volgens hierdie beskouing is politieke beleid oorsaak van trekarbeid. Ekonomiese determinasie moet dan dié beleid ophef.

Kerklike standpunte oor trekarbeid spits meesal op die simptome en gevolge toe. Beoordeling en veroordeling van trekarbeid kan slegs sinvol geskied wanneer die werklike oorsaak onder oë gesien word.

\section{Implikasies van trekarbeid}

4.1. Trekarbeid gaan by die arbeider en werkgewer mank aan „production-orientation" mis 'n oriëntasie op die mens. ${ }^{10}$ Trekarbeid misken verskynsels soos die taal, kultuur, godsdiens en identiteit van die trekarbeider. Hy word benader met 'n soort geestelike en menslike „fanakalo" ter wille van sy arbeid. Gevolglik word beweer dat die trekarbeider verontmens en van "sy menseregte" beroof word. ${ }^{11}$

4.2. Trekarbeid hou risiko's en gevolge vir die familielewe van die trekarbeider in. Veral die getroude trekarbeiders werk buite sy gesin, vervreem, lei seksueel 'n abnormale lewe. Hy kompenseer in homoseksualiteit of verwek in konkubinate tweede gesinne. Wanneer hy tuiskom is hy nie meer 'n geesgenoot van sy vrou en gesin nie. In die tuisland waar vroue sonder mans verkeer, word talle tot ontug verlei. Ander word geleidelik verwaarloos (ook finansieel). Kinders groei op in vaderlose huise, sonder gesag en tradisionele dissipline sodat hulleself ook weer maklik tot prooi in misdaad en sedelose praktyke val.

Jong mans- en meisietrekarbeiders akkultureer in 'n sfeer van normlose vryheid, verwyder van die tradisionele patriargale of matriargale gesag, stamwette en kultuur. Wanneer hulle terugkeer, het hulle reeds vreemd aan die eie groep geword. ${ }^{12}$

4.3. Prof. Noel C. Manganyi ag die verlies van identiteit selfs nog skadeliker: „Perhaps more disturbing than the disruption of family life... are the implications for nationhood..." Hy praat van 'n skadelike „patchwork identity of the migrant mine worker" wat 'n "tragic lack of force, continuity and creative thrust" veroorsaak. Sy verdienste mag moontlik iets bydra om lewe in die tuisland aan die gang te hou. Hy is as mens egter nie betrokke by die ontwikkeling van die tuisland nie. Die trekarbeidsisteem verlam ekonomiese vooruitgang in die tuisland. Eie en groepsvooruitgang word steeds sterker met arbeid in die Blanke areas geïdentifiseer. Onverantwoordelikheid teenoor die eie en afhanklikheid t.o.v. onderneminge van 
die Blanke veroorsaak 'n identiteitskrisis.

4.4. Die stilstaande en selfs agteruitgaande ekonomie in die tuistes gepaard met afhanklikheid van 'n verre vreemde ekonomie, veroorsaak sonder toestromingbeheer die skrikwekkende toestande wat rondom die stede in die jare dertig en veertig voorgekom het: behuisingsnood, goedkoop arbeid, sjebeens, ontugvroue, kinderverwaarlosing, armoede, higiëniese ramptoestande, misdaad, ens. Daaruit ontstaan weer bitterheid by individue en groepe teen die instansie wat instroming beheer en repatrieer. Agitators en werkloses kan die ,griewe" uitbuit en voorgee dat die swartman "slaaf" van die witman is. Self doen die swart individue en regerings niks om die chaos op te ruim nie.

4.5. Trekarbeid kweek van jongs af die suggestie by die Bantoe dat die stad sy lewensnood sal lenig, lei na onbeheerbare verstedeliking en gesentraliseerde en geïntegreerde ekonomie. Die verstedelikte Bantoe dink almeer stedelik en individualisties. Hy word maklik die prooi van politieke agente wat sy griewe aksentueer. Daar moet noodwendig meer wetgewende maatreëls getref word om op allerlei vlakke wrywing en botsing te probeer uitskakel. Die maatreëls aksentueer op hulle beurt griewe en die gevolg is toenemende binne en buitelandse veroordeling van die beleid van veelvolkige ontwikkeling. ${ }^{13}$

4.6. Van kerklike kant word besondere probleme en implikasies ontmoet:

4.6.1. Die trekarbeider is feitlik kerklik onbedienbaar. Die Bantoe is van nature mens-in-gemeenskap en derhalwe wil hy ook sy kerklike en godsdienstige lewe as sodanig voer. Sodra hy in die trekarbeid-sisteem geîsoleer is, is hy afgesluit van sy normale religieuse belewing en uitlewing. ${ }^{10} \mathrm{Hy}$ is gewoond om godsdienstige handelinge (bv. met huwelik, geboorte, begrafnis) by sy tuiste en onder sy mense te verrig. „It has become necessary for the Church to regard the migrant labourer at all times as a man from his homeland. - A city congregation with various languages, cultures and different ways of worshipping is - simply not able to do justice to the constructive service to migrant labourer". Die toespitsing op die enkeling in die trekarbeid-sisteem deur 'n "special ministry" het alleen beperkte waarde tensy 'n lewendige ,feed-back" met die gemeenskap in die tuisland bestaan. ${ }^{14}$ Engelse kerkmanne stem saam en sê dat indien kerke „,continue treading the present well-known path of church ministry, they will by-pass the migrant people they most want to reach and serve ..." 10

4.6.2. Uit voorgaande volg dat trekarbeid gemeentevorming en opbou onmoontlik maak. Trekarbeiders kan geen erkenning of gevoel van waardigheid in 'n bestaande gemeente verwerf nie.

4.6.3. Die Bantoe se morele bewussyn rus nie soos dié van die Blanke Christen op ' $n$ besef van skuld teenoor en verantwoordelikheid aan ' $n$ Hoër Wese of selfs sy voorvaders nie.' Die Bantoe het tradisioneel 'n swak ontwikkelde waarde en normsisteem en hou gevolglik 'n losser opvatting sonder intieme emosionele verwantskap oor huwelik, familielewe ens., daarop na. Derhalwe vind 
sedelike en seksuele afwyking in prostitusie, buite-egtelike verkeer, konkubinaat, homoseksualiteit, aanrandings ens. makliker plaas.

4.6.4. Die feit dat trekarbeid slegs deur behoeftes aan loon gemotiveer word, laat die trekarbeiders as mens onbevredig. Arbeid word blote pligpleging, oorsaak vir rassehaat en geen christelike arbeidsetiek kan posvat nie.

\section{Die begin van kerklike bemoeiing met trekarbeid}

\subsection{Internasionale bemoeiing}

In die tyd van die Hervorming het Calvyn die beroep van huursoldaat op grond van die euwels wat dit meebring, afgekeur. Aan die ander kant is maandelange seevaart en gesinsontwrigtende en sedelose gevolge daarvan min of meer gelate aanvaar. Tot vandag toe swyg kritici van trekarbeid in Suid-Afrika oor stelsels van seevaart in hulle eie lande. Die stelsel van trekarbeid leen hom vir 'n aanval op kapitalistiese stelsels dwarsdeur die wêreld (terwyl "trekarbeid" en dwangarbeid in kommunistiese lande betreklik skotvry gelaat word).

Kragtens die berekende linkse strategie en programme vir struktuurverandering het die Wêreldraad van Kerke aandag op trekarbeid gevestig. In Suid-Afrika is instromingsbeheer deur middel van passe en bewysboeke as diskriminasie in diens van ,apartheid" aangedui en so as "rassisme" gebrandmerk. Die onluste te Sharpeville en Langa is in 1961 deur linkse en dikwels blanke stratege uit die internasionale bemoeiing vir struktuurverandering met agitasie teen die bewysboeke aangevuur.

In dieselfde jaar waarin Sharpeville beplan is, is in Switserland 'n konferensie oor trekarbeid gehou. In 1964 het die WRK 'n komitee gevorm om trekarbeid dwarsdeur die wêreld met 'n omvattende ,program" te bekamp. Trekarbeid staan die eenwording (sosialisering) van die mensdom in die weg en leen hom dus om met die oog op rewolusie uitgebuit te word.

In die res van die wêreld word trekarbeid min of meer intakt gelaat. In 1971 het Adjunk-Minister P. G. J. Koornhof opgemerk: „Sekere organisasies verwyt die Regering ook dat hy trekarbeid toelaat. Dit is nie duidelik waarom Suid-Afrika nou juis uitgesonder word vir hierdie soms venynige, aanvalle nie..." ${ }_{3}$ Ek meen dat die rede vir die aanvalle in die Suid-Afrikaanse kapitalistiese ekonomie (bv. mynbou) sowel as die veelvolkige ontwikkeling geleë is wat albei die neo-imperialisme uit sosialistiese en panafrikanistiese hoek in die weg staan.

'n Mens onderken maklik ' $n$ min of meer enerse en sosio-politiesgelade ondertoon in die proteste van ,organisasies” soos die Christelike Instituut, Instituut vir Rasse-aangeleenthede, Black Sash, SACCA, Sprocas en Kerke wat die kondisionerende „program” van die WRK bevorder.

Gelukkig het die N.G. Kerk in Kaapland in 1965 die probleem begin bestudeer. Die waarde van 'n gebalanseerde visie binne die N.G. Kerk-familie was te Umpumulo 1970 merkbaar. Die NGKSA verdien vir hierdie grootse taak dank in Suid-Afrika. Die standpunt 
van die GKSA leun ook op hierdie studiemateriaal aan.

\subsection{Die driehoekooreenkoms in SWA}

Twee Lutherse Kerk (ELOK en ELK) en die N.G. Kerk het in Mei 1947 met die oog op die bearbeiding van Ovambo-trekarbeiders ooreengekom dat die ELOK evangeliste sal oplei en uitstuur, die ELK (Rynse) sou geboue beskikbaar stel en die NGK sou finansier. Uit hierdie aksie is reeds vertoë gebore waardeur die termyn van kontrakte op een jaar vasgestel is. Hierdie aksie het egter nie trekarbeid as sodanig nie, maar die gevolge daarvan probeer verlig en ophef.

\subsection{Beraad te Umpumulo 1970}

Die Missiologiese Instituut van die Lutherse Teol. Kollege het in samewerking met die Christelike Akademie in Suidelike Afrika en die Instituut vir Rasse-aangeleenthede 'n beraad oor trekarbeid van 27 Augustus tot 23 September 1970 te Umpumulo georganiseer. Lutherse, N.G., Amerikaanse, Metodiste en NGKA het verslae voorgelê. Waarnemers en verteenwoordigers van Anglikaanse, Kongregasionaliste, GKSA, talle Lutherse gemeentes, Metodistiese, Morawiese, NGKSA, NGKA, Presbiteriaanse en Rooms-Katolieke Kerk sowel as verteenwoordigers van SACCA, Transkeise Raad van Kerke, Instituut vir Rasse-aangeleenthede, SABRA, en die Teologiese Kollege Umpumulo en die Christelike Akademie in Suidelike Afrika was teenwoordig. Die referate is vir hierdie voordrag geraadpleeg.

Volgens die samevatting van die organiseerders ${ }^{16}$ is beoog ,to further steps towards a fuller and more compassionate engagement in problems pertaining to the migratory labour issue". Migrasie van werkers is 'n wêreldverskynsel "maintained by the push and pull of economic forces" met ekonomiese, sosiale, kulturele, morele, wetlike, politieke en godsdienstige implikasies vir die trekarbeiders, sy gemeenskap, volk en vir Suid-Afrika en Suidwes-Afrika as geheel. Trekarbeid as sisteem ,is fairly generally regarded as morally undesireable and should, therefore be eliminated as soon and as far as possible... It seems that the churches would like to see an economy which would ensure the maximum opportunity for stable family life..."

Die owerheid beoog tuislande vir die ,ethnic groups" en werkgeleentheid digby die tuistes „thereby meeting political and economic requirement". Ondertussen moet die tuislande arbeid uitvoer. Verstedeliking moet aanvaar en die oorgang van landelike na stedelike bestaan vir die Bantoe vergemaklik word. In Blanke en tuislandstede moet die arbeiders met hulle families saamlewe.

Veelvolkige ontwikkeling en ekonomiese groei vereis 'n permanente en groeiende swart arbeidsmag. Die verwagting dat veelvolkige ontwikkeling die aantal trekarbeiders sal verminder is in stryd met ekonomiese berekeninge.

Werkgewers moet lone sodanig bepaal dat die trekarbeider vir homself en sy familie kan sorg. Arbeidsopleiding sal armoede as blywende gevolg van trekarbeid uitskakel. Met ontsteltenis word 
die oprigting van kampongs (compounds) by grensnywerhede waargeneem.

Die kerke moet slegs deur gehoorsaamheid aan die Woord van God gemotiveer 'n profetiese en pastorale taak ten opsigte van die trekarbeiders vervul en hulle behoeftes en probleme onder oë sien. Die roeping moet ook teenoor die owerhede en werkgewers uitgeoefen word. Dit is nie die taak van die kerk om 'n sosiale struktuur te ontwerp nie. Die kerk moet die norme van die koninkryk van God proklameer en toepas sodat man, vrou en kinders saamlewe „,in the security of family life".

Die „religious training" moet die mense leer wat sinvolle familielewe, christenskap, vryetydsbesteding, ens. beteken.

\subsection{MIK (AIM)-konferensie te Jan Smuts 18 en 19 Januarie 1976}

Die Genootskap vir die Mens in Industrie en Kerk (MIK) of Agency for Industrial Mission (AIM) het as konvenor opgetree vir die Interdenominational Committee for the Witwatersrand Industrial Mission (gestig 1966) waar die rol van die kerk onder trekarbeiders op die myne onder die soeklig geplaas is. Die voorkoms moes internasionaal en interdenominasioneel wees. Die deelnemende kerke is Anglikane, Lutherane, Paryse Sendinggenootskap, Metodiste, NGKA, NG Sendingkerk, Presbiteriane, Kongregasionaliste en Baptiste met Roomse waarnemers. Lesotho was sterk verteenwoordig en tuislandleiers, koerante, Black Sash en akademici het die byeenkoms bygewoon.

Dit is opmerklik dat so 'n aksiegroep hulle in besonder rig op die „mens" en „,sending" onder mynwerkers. Onwillekeurig wonder 'n mens waarom na Umpumulo 1970 nie kerke nie maar hierdie frontorganisasie hom verder met die problematiek bemoei. Persoonlik plaas ek maklik 'n vraagteken agter hierdie dikwels „linkse" strategie waarin 'n organisasie onder 'n "menslike" en ",internasionale" pose inisiatief neem om bestaande kerkstrukture by hulle „program" te betrek. Ek laat hierdie konferensie uit die oogpunt van „kerklike standpunte" buite rekening, dog sal na referate van enkele spre. kers verwys.

\section{Enkele kerklike standpunte}

\subsection{Standpunte met 'n oorwegend Europese of Neo-Imperialistiese visie}

6.1.1. Die Neo-imperialistiese visie. Elders het ek probeer om die begrip „kolonialisme" wat onlosmaaklik met imperialisme saamhang, te ontleed en sy kenmerke bloot te lê. ${ }^{18}$ Kolonialisme het kulturele identiteite en geografiese eenhede in die imperiums verswelg. In Suid-Afrika het Britse imperialisme vanaf 1875 verskillende nasionale volke en state (Xhosas, Zulu's, Transvaalse en Vrystaatse Republieke, afsonderlike Swart state in Transvaal) met geweld opgeslurp en in die Unie van Suid-Afrika in 1910 ondergebring.

Kolonialisme (imperialisme) is basies deur 'n ekonomiese motief beheers (merkantilisme). Ryke is met die oog op stoflike belange 
gestig. Tweedens het imperialisme van Europese feodalisme uitgegaan. Die Europeër was steeds die leenheer, ondernemer, beskermer en voog van die ,inboorling" wat in ruil vir sy arbeid in sekere „voorregte" van die ryk van die heer gedeel het. Derdens het die imperium berus op die kultuur-monopolie en kultuur-supremasie van die bepaalde Europese moondheid. Dit was asof ander kulture en etniese identiteite binne die imperium eenvoudig nie bestaan het nie. Imperialisme kan nie met afsonderlike volke (wit of swart) en etniese identiteite reken nie. Hy gaan slegs van die kultuuridentiteit van die veroweraar uit.

In Suid-Afrika is alle swart kulture deur die Engelse voogdelik en meerderwaardig vir ,primitive" en ,uncivilised" gehou. Selfs die Afrikaners is as "primitive Dutch" gebrandmerk en moes in die Engelse kultuur-imperium opgaan. Beskawing en ontvoogding is met verengelsing en verwestersing vereenselwig. Weinig Engelse of Europeërs het met die Afrikaner se kultuur en godsdiens ingeval.

Imperialisme het 'n politieke en geen etniese vertrekpunt nie. Trouens British nation is 'n imperium van ,ethnical groups" (bevolking). "Volk" en "nasie" is 'n struikelblok vir integrasie en „eenheid". Die staat maak 'n „,nation”. Die oomblik wat hy 'n volk oorwin en sy politieke gesag vestig, het daardie volk een met en deel van die British nation geword. Die Europeër is die subjek en die ,inboorling” die objek in die staat-maak proses. Daarop rus die tipiese kolonialistiese dualisme van "we" en "they" of van „european" en ,,non-european” wat later met „blank” en ,nie-blank” en vandag in Europa veral met ,wit" en "swart" vertaal word. Laastens berus imperialisme op ' $n$ religieuse geloof in die mens (humanisme) en 'n universele eenheid van die mensheid.

Gedurende die vorige eeu het sendinggenootskappe, dikwels gesteun deur kerklike (filantropiese) standpunte, die Britse imperium in Suid-Afrika ingedra. Die Wes-Europese mens is vandag gemotiveer vir 'n groter imperium, 'n oorkoepelende superstruktuur, 'n mundiale eenheid waarin slegs die begrip "mens" norm en kriterium is. Daar word gesoek na die imperium van die mensheid. Hierdie neo-imperialisme het talle fasette, byvoorbeeld pan-afrikanisme, kommunisme, sosialisme, swart "nasionalisme" wat in wese rassisme is, ekumenisme, ensovoorts. Die neo-imperialisme is nietemin net soos die ou Europese imperialisme ekonomies geinspireer en gerig op 'n „gelyke verdeling" van die wêreldekonomie. Europeërs bring die nuwe imperium nog steeds „vaderlik" vir die „swartes” en aanvaar dat hulle beter as die swartes weet wat vir die Derde Wêreld nodig is. In Europa kan hulle wel onderskei tussen nasionale identiteite maar in Afrika beskou hulle almal „Blacks" of "Africans” en in Suid-Afrika is almal ,South Africans". In teorie bestaan daar vir die moderne Europeër geen etniese differensiasie nie. In praktyk neem die neo-imperialis aan dat almal soos hy sal word, sy taal sal praat, sy kultuur sal oorneem. Vir hom is "Suid-Afrika" wat die Britse en S.W.A. wat die Duitse gewere gemaak het, een land waarin een volk of ,bevolking" woon. Die mens en menslike is die kriterium en na geskiedenis, historiese woonplek, identiteit van gemeenskap en kultuur, word nie gevra nie. Hierdie neo-imperialistiese 
visie op 'n mundiale mensheid en ongedifferensieerde „Suid-Afrikanerskap" kom ook in talle kerklike standpunte oor trekarbeid buite en binne Suid-Afrika na vore.

6.1.2. Standpunt van Lutherse kerke. Hierdie kerke is lank reeds betrokke by die trekarbeid in S.W.A. Die ELK en ELOK het hulle aanvanklik toegespits op kerstening en bediening van Ovambo trekarbeiders. Hulle het byeenkomste, kursusse en gebede vir die trekarbeiders gestimuleer. Hulle het aangedring op korter kontrakperiodes, die noodsaaklikheid van vrouebesoeke en hulle het seksuele misstande soos homoseksualiteit in die mynkampongs bestry. ${ }^{17}$ Die Sinode van die ELK het in 1970 verklaar: Die gesinslewe is die grond. slag van 'n gesonde samelewing en kerk. As die kerk iets vir sy mense moet doen, dan is dit om vir hulle 'n gesinslewe moontlik te maak. ${ }^{18}$ Op 30.6.1971 het die ELK en ELOK plotseling meer aggressief 'n ope brief aan die Eerste Minister gerig. Daarin beweer hulle dat die S.A. Regering gefaal het om menseregte aan die „Nie-Blanke” inwoners van Suidwes-Afrika te verseker. In 1972 word pastoor Althaus die eerste persoon uit die geledere van die ELK wat om politieke redes uit Suidwes-Afrika verban is.

6.1.3. Standpunte onder Anglikane. Anglikaanse kerkleiers is by uitstek daarvoor bekend dat hulle heftig aangeval het op haas elke faset van die Afrikaanse volkerebeleid. Hierdie geestelikes verteenwoordig enersyds die anti-Afrikaanse en andersyds die neo-imperialistiese visie. Sommige het reaksie teen die identiteitsdokumente (passe) en toestromingsbeheer aangeblaas en was gemoeid by die onluste van Sharpeville en Langa (1961). Werkreservering, afsonderlike woongebiede, ontugwetgewing ens. is gedurig aangeval. Enkele name soos Joost de Blank, Huddleston, Reeves, Collins, Crowther en Winter illustreer onmiddellik hoe sosio-politieke ideologië onder die gesag van Anglikaanse kerklike ampte aangebied is. Die antiregerings en anti-Afrikaanse ideologië uit hierdie kerklike milieu is soms woordeliks verwant aan die opvattings van linkse aksiegroepe soos die „Black Sash”, SACCA, Institute for Race Relations ens. „Kerklike” en „politieke" standpunte vloei by talle van hierdie kerklike figure heeltemal ineen en kom ooreen met wat as neo-imperialisme en neo-marxisme bestempel word.

Trekarbeid en instromingsbeheer moes logies die skyf word nadat die paswette in 1961 vir die rewolusie geëksploiteer is. Black Sash van Mei 1974 haal gevolglik die Aartsbiskop van Kaapstad aan wat trekarbeid in Suid-Afrika aan 'n ,ideologie" toeskrywe: "South Africa has chosen to make migratory labour a permanency, keeping the vast majority of its labour force perpetually oscillating between rural and urban areas. This leads to economic, social, medical and religious evils which can no longer be tolerated in a professedly Christian (country). It is the duty of all Christian bodies to say so. The deliberate disruption of family life at the dictates of an ideology is a blot which must be eradicated by those who have the means and the power to do so. Christian conscience will not be silenced until this happens".

Die uitspraak negeer eenvoudig die feite van wêreldwye voorkoms en historiese ontwikkeling van trekarbeid in Suid-Afrika om 'n 
bepaalde polarisasie te bevorder. Toe die Minister verklaar dat hy ook teen trekarbeid gekant is, het Dean Tutu op die MIK-konferensie te Jan Smuts 1976 ruiterlik bely: „I, myself, must confess that I am deeply moved by this governmental acknowledgement because I was under the impression all along that this utterly reprehensible labour system appeared to be the keystone in the apartheid super structure..." Dit moet spoedig beëindig word, "with avoiding colossal social disruption and disorganisation". Ons mag „prosperity” nie koop teen „too great a cost in human misery and suffering" nie. ${ }^{19}$

'n Mens kry die indruk dat Anglikaanse kerklike standpunte eensydig en gepolariseerd trekarbeid aan ,apartheid" toeskrywe en dus op trekarbeid aanval om veelvolkige ontwikkeling te verydel ten gunste van 'n geintegreerde (swart en Anglisaksiese) Suid-Afrikaanse imperium. Die gebrek aan kommunikasie en feit van gepolariseerde voorligting is uit die opmerking van Tutu duidelik.

Tutu het ook 'n oog daarvoor dat trekarbeid die tuislande verarm: "Our prosperity is being generated at the expense of the increasing poverty of the homelands which are reservoirs of cheap labour, which are denuded of their young people and strong male folk and also denuded in their soil through poor agricultural methods, and at the expense of their children, who are always the victims of malnutrition. ... We must urge the relevant authorities on moral and theological grounds, as well as for the sake of expediency and self interest to improve the living conditions of the migrant labourer..." Hy verlang familiebesoeke, pleeggesinne en familiehuisvesting vir die trekarbeider en wil die arbeiders in vakbonde organiseer om te veg teen hulle verontmensing. Hy wil konkubinaat nie so skerp veroordeel nie.

By Tutu skemer die tradisionele (Blanke) Anglikaanse antagonisme deur, maar tog klink die stem van realisme en die hartklop vir die tuisland ook op. Hy wil trekarbeid selfs genuanseerd afskaf.

6.1.4. Die Methodist Church of S.A. Te Umpumulo in 1970 het eerw. O. Banwell gesê dat die Metodiste Conference sedert 1965 hom sterk teen die sisteem van trekarbeid verklaar het. Gepaard met hierdie kritiek skep die Metodiste positief werkgeleentheid in tuislande. Daarvoor is 'n maatskappy Mbazi gefloteer om Zulu skrynwerkers en bouers binne die tuisland aan werkgeleentheid te help in projekte van hervestiging, huisbou en kerkgeboue. Die mense kry so geleidelik ervaring om later self as ondernemers te kan optree en die kerk benut die geleentheid vir sending.

6.1.5. Standpunte in die Rooms-Katolieke Kerk. Te Umpumulo in 1970 het pater F. Synott ${ }^{20}$ "strong moral condemnation" oor trekarbeid uitgespreek. Hy skryf dit aan „casual colonisation" waaraan ons almal skuld het, eerder as aan die Regering wat ,in the trap of history" gevang is, toe. Hy wil ook nie "evil motives" by diegene wat ,so far failed to find means of justice and humanity sufficient to clear up our problems" soek nie. Die probleem van trekarbeid sal oornag verdwyn indien "Africans" toegelaat word om hulle families te hê waar hulle werk. "It is only the principle of racial segragation, for which people are prepared to override all ordinary norms of 
humanity or human rights or ethics, that dictates this situation. It can blind men to the fact that they are using others as things not persons, footpounds of energy, not human beings with common needs and the dignity of nature of men".

Eerw. Cosmas Desmond van Johannesburg is in Junie 1971 gedeporteer. Hy het op die personeel van die Christelike Instituut gedien. In 'n voorligtingstuk wat die joernalis Robert van Waesberge in 1974 op versoek vir die Sinode van die Nederlandse Hervormde Kerk oor Suid-Afrika saamgestel het (,Apartheid, hebben wij er part aan?") en waarin trekarbeid voorgestel word as 'n meedoënlose sisteem van opgebruik van mense om hulle daarna afgeleefd in onherbergsame tuislande op te hoop, word Desmond saam met outoriteite soos Winter, F. Wilson, Braun, Hepple, Sprocas en ander kwistig aangehaal om die Nederlandse Herv. en Geref. Kerke in die program van die WRK teen Suid-Afrika op te hits.

6.1.6. Enkele individuele politiek-morele en semi-kerklike standpunte. Die politiek-sosio-religieuse Westerse lewensbeskouing binne die neo-imperialisme is nie beperk tot sendelinge, kerklike konferensies en linkse aksiegroepe nie.

F. van Wyk van die SAIRR het te Umpumulo in 1970 trekarbeid verwerp en tegelyk hierdie imperiale (d.w.s. oorkoepelende) ideaal onomwonde bely as „one undivided economy in an undivided South Africa". ${ }^{21}$ Vanuit hierdie neo-imperialistiese vertrekpunt wat reglynig op Suid-Afrika as resultaat van Britse imperialisme voortbou, ontwyk hy dr. C. J. Jooste se veelvolkige standpunt ${ }^{22}$ wat minstens die historiese, momentele en eksistensiële realiteit reflekteer.

Black Sash wy die nommer van Mei 1974 aan standpunte oor trekarbeid. G. Dyzenhaus tipeer 'n trekarbeider (uit 'n tuisland) neo-imperialisties as ,a South African working in the land of his birth" wat belet word om sy vrou en familie by hom te hê terwyl hy werk. Slegs die 12 persent buitelandse trekarbeiders kan met Europese trekarbeid vergelyk word. Sheena Duncan hou 'n „master plan" verantwoordelik dat die Blanke in "dieselfde" land regte het wat 'n Swarte nie het nie. Joyce Harris verwerp die idee van tuisland, omdat dit geen eienskap van 'n „tuiste" het nie: die stamlewe is ontwrig, die gebied is oorbevolk en massas mense van "this land" word nie toegelaat om as gesinne te woon, werk en vestig waar hulle wil nie. Francis Wilson dink in terme van "we" en "they" en verklaar met skuldgevoel: „We use their labour and abuse their humanity". 'n Mens voel die emosionele drakrag in derglike argumente wat eenvoudig die Britse imperium basis vir Suid-Afrikaanse burgerskap maak en historiese lande en volke ignoreer.

Die medikus Anthony Barker van Nqutu (Zululand), medewerker aan die film "Last grave at Dimbaza”, maak ook trekarbeid as onmenslike resultaat van ,apartheid" af en sê in dieselfde trant in South African Outlook ${ }^{23}$ dat die tuislande slegs sentra van "loneliness" is. Hy voel duidelik geen band aan die grond nie. Familieontwrigting as gevolg van trekarbeid skryf hy toe aan die ,hypocrasy of a society that preaches the sanctity of the home (unlike those villainous communists...) and then denies men and women the chance to found anything of the kind". Beter mediese dienste lei 
na oorbevolking en gevolglik beskou hy trek „beyond our boundaries, and join the great mass" as enigste oplossing. "No matter what cony words we use (and 'homeland' sounds much more attractive than the older 'reserve') the fact remains that a homeland is a place where no man can live for longer than a few months together with his family without necessity of getting out of it ..." Hy blameer die ekonomiese determinasie van die Blanke vir ,all this pain" van die „black man”. Eerw. Dale St John White verwerp trekarbeid as demoniese en onpersoonlike sisteem. Kampongs vergelyk hy met tronke en militêre barakke, uitvloeisel van 'n ekonomiese stelsel wat apaties staan teenoor menswaardigheid. Die stelsel is "production-orientated" en nie mens-georiënteerd nie. ${ }^{10}$

Derglike sienswyses korreleer met die ,kerklike" standpunte, waarskynlik omdat 'n legio „aksie"-organisasies soos IRA, CI, Black Sash, MIK (AIM), met 'n bepaalde ,program" (wat iewers buite S.A. gekoppel mag wees) bestaande strukture soos kerke inspireer om daarmee besig (,involved") te raak, asof 'n blote humanitêre en ekonomiese imperium die enigste oplossing bied.

6.1.7. Opmerking: Hierdie tipe ,kerklike" betrokkenheid is eensydig. Dit verraai nog die tipiese Westerse voogdelike en paternalistiese monopolie dat die Blanke ekonomie, werkgewer en politieke owerheid alleen skuld dra vir die ,euwels" en ook alleen vir die oplossing verantwoordelik is. Hierdie ideologie vertrou grensloos op die patroon van geïntegreerde polarisasie, metropole, massas en tegniek. Die Swart man en sy tuisowerhede word nergens as mondige mens-in-gemeenskap self opgeroep om op sy toekoms te antwoord nie. Ten spyte van al die vroom voorgee, is die „swart man" vir hulle gedegradeer tot 'n mens sonder gemeenskap, 'n individu alleen, iemand wat vrylik na die stad met sy familie moet gaan om te werk - en geen ander en hoër menslike en kulturele identiteite moet verantwoord nie. Trouens waar en in watter taal moet hy skoolgaan en watter kultuur moet aan hom oorgedra word - syne of dié van sy Westerse skynbare weldoeners?

Hierdie neo-imperiale denke het nietemin werfkrag. Ds. Sam Buti het op die jongste Sinode NGKA feitlik woordeliks soos Dyzenhaus van 'n imperiale Suid-Afrikanisme en burgerskap uitgegaan. ${ }^{24}$ Ken hy as Sotho Suid-Afrika fenomenologies as so 'n „eenheid" of het hy die imperium in hierdie ,skool" leer ken?

\subsection{Standpunte by Blanke Afrikaanse kerke ${ }^{\text {s }}$}

6.2.1. Die Ned. Geref. Kerk in S.A.

6.2.1.1. Sedert die deurtastende ondersoek na trekarbeid in Kaapland in 1965 onderneem is, het die Algemene Sinode (Oktober 1966), die Federale Raad (1968), en weer die Algemene Sinode (1970) daaroor gehandel. ${ }^{20}$ Die Breë Moderatuur het ondertussen ook die kern van die standpunt gepubliseer in ,Ras, Volk en Nasie en Volkereverhoudinge in die lig van die Skrif" (1975).

6.2.1.2. Hierdie omvattende en akademiesverantwoorde ondersoek bevind dat trekarbeid geen geïsoleerde SA-verskynsel of van resente datum is nie. Die sisteem het stadig uit ekonomiese motiewe ontwikkel omdat daar naas die nadele ook definitiewe voordele aan 
die stelsel verbonde is.

6.2.1.3. Onder nadele word genoem dat die stelsel grotendeels verantwoordelik is vir die instorting van die huislike lewe van die Bantoe en ernstige sosio-godsdienstige probleme meebring. Dit lei by duisende mans tot verwaarlosing van die huisgesin, tot aanrandings, seksuele afwykings, gevegte en tot ellende by baie huisgesinne in Bantoetuislande. Nòg 'n stabiele sosiale lewe, nòg 'n behoudende middelklas kan so by die Bantoe opgebou word. Die Blankes staan voor die probleem van oorindiensneming (en verlamming omdat hulle arbeidsku word) en toenemende verbittering kom by die Bantoe voor. Dit lei tot die grootste enkele probleem vir die kerk in sy poging om 'n gemeente van Christus en 'n Christelike samelewing onder die Bantoe tot stand te bring.

6.2.1.4. Die stelsel hou nietemin ook groot voordele in. Dit lewer 'n noodsaaklike bydrae tot die ganse ekonomiese struktuur van die land. Dit red die Bantoevolksgroepe van totale insinking en hongersnood. Dit lei die Bantoe op in die Westerse arbeidstruktuur en bevorder eie industrialisering onder die Bantoe. Dit verlig die ekonomiese druk op die tuislande. Dit handhaaf en bevorder goeie orde op sosiale en ekonomiese terrein en voorkom arbeids- en stedelike chaos.

6.2.1.5. Die geĩnstitueerde kerk is nie geroepe om die oplossing te vind nie. Dit moet deur deskundiges uit verskillende akademiese lae gevind word. Die kerk moet egter die morele en skrikwekkende gesinsontwrigtende gevolge van hierdie „kanker" aandui wat die sosiale en godsdienstige lewe van die Bantoe aantas. „Die Blankes sal kragtens die wette van God nie onaangeraak bly van die siektes wat die Bantoe se morele lewe verwoes nie. Om te argumenteer dat die trekarbeidstelsel ' $n$ tydelike maatreël is, is wensdenkery wat vir die kerk in die Republiek rampspoedige gevolge mag hê".

6.2.1.6. Die kerk dring aan dat die staat 'n deurtastende ondersoek na die stelsel instel met die doel om dit te verander sodat die nadele verwyder of ' $n$ nuwe stelsel ontwerp word wat die voordele van die oue sonder sy nadele kan behou. Die NGKSA vra dat die owerheid die ontwikkeling van tuislande en grensnywerhede bespoedig en trekarbeid geleidelik beëindig.

6.2.2. Die Gereformeerde Kerk in Suid-Afrika (GKSA)

6.2.2.1. Die Sinode van 1976 het standpunt oor trekarbeid gestel wat grootliks op die grondliggende werk van die NGKSA steun. Prinsipieel heers eenstemmigheid terwyl slegs enkele aksente sterker of anders gelê word. Reeds in 1973 is verklaar dat die kerk hierdie probleem nie kan oplos nie. ${ }^{27}$

6.2.2.2. Trekarbeiders het ondertussen in Blanke gebiede nie verminder nie, maar vermeerder, soos prof. J. H. Coetzee ook in Woord en Daad van Julie 1975 aangetoon het. Die Sinode sê dat wanneer slegs een Blanke spil die veelvolkige ekonomie moet draai, sal die owerheid die ,morele reg verloor om 'n tuislandbeleid en die bestaande stelsel van trekarbeid as oorgangsfase te verdedig. Vanuit die verklaarde beleid van afsonderlike en selfregerende tuislande vir afsonderlike volke, het die kerk die reg en roeping om die owerheid op te roep tot grootse pogings ten einde te verseker 
dat reg sal geskied aan alle belanghebbende volke van die land".

6.2.2.3. Die grensnywerheidsprogram word betwyfel omdat by die nywerhede weer kampongs opgerig word wat steeds op familieontwrigting dui.

6.2.2.4. Die kerk moet die burgery opvoed om die probleme van die trekarbeider te begryp en veral in die tuislande pastoraal en kategeties die gesinne begelei, geestelik weerbaar maak en motiveer om self die nadele van trekarbeid in te sien en dit binne en buite die tuisland te bekamp. Swart leiers moet gevorm word om roepingsbewus die probleme aan te durf en alternatiewe vir trekarbeid te ontplooi. Die Swart volke moet toenemend met die christelike ar. beidsroeping gemotiveer word tot persoonlike arbeid, onderneming en bydrae tot ontwikkeling van eie bodem en potensiaal. Sonder hierdie mensverandering sal niks in eie kringe op dreef kom nie en bly die mense genoodsaak om uit te wyk ,en dikwels ander na die oë te sien".

6.2.3. Opmerking: Die standpunt van die vorige kategorie ,europese" kerke het trekarbeid aan die beleid van afsonderlike ontwikkeling gewyt. Mens sou dan verwag dat die Afrikaanse kerke trekarbeid op grond van die beleid van afsonderlike ontwikkeling sou probeer regverdig. Die Afrikaanse kerke veroordeel egter juis trekarbeid op sterkte van dié beleid van veelvolkige ontwikkeling. Waar sentralisasie en integrasie (neo-imperialisme) van Swart in Blanke stede, ekonomie, maatskappy, kultuur, die standpunt van daardie kerke gekenmerk het, dring die Afrikaanse kerke aan op ekonomiese desentralisasie, differensiasie en kragdadige ontwikkeling van die mens en potensiaal in eie reg, identiteit en selfstandigheid binne sy natuurlike tuiste en milieu. Op morele gronde is die kerke nie te vinde om met die ekonomie tot 'n vergelyk te kom nie en roep die regering op om sy erns met die mense (beleid) ook in dade te toon.

\subsection{Standpunte in Swart Afrikaanse kerke}

6.3.1. Die Ned. Geref. Kerk in Afrika (NGKA)

6.3.1.1. Mnr. F. R. Mohlabe van Bloemfontein het te Umupumulo in $1970^{20}$ aangetoon dat die motief tot 'n geldekonomie, selfvoorsiening en verandering in die tuislande nog heeltemal ontbreek. Geldmaak word met die Blanke dorpe en stede geassosieer en trekarbeid „contributed to the negative development of the homelands". Die individualistiese benadering van die Blanke tot arbeid ken die Bantoe nie. $\mathrm{Hy}$ is in wese gemeenskapsmens. Die gevolge op die morele en gemeenskapslewe is funest.

6.3.1.2. Die Algemene Sinode van die NGKA het te Tshilidzini in 1971 vertoë tot die Regering gerig om die ,effek van trekarbeid" te verlig deur voorsiening van beter huisvesting, ontspanning, korter kontrakte, ens. Die Sinode dring aan op ontwikkeling van grensnywerhede en tuislande. Die kerk moet in die tuisland die mense motiveer met die oog op ontwikkeling. Indien Blanke gebiede oopgestel word vir Swart immigrasie, sou die probleem vermeerder: Swart gesinne in die tuislande sou nog geraak word; lewensstandaard van Swart werkers sal daal deur verarming en chaos. Tegelykertyd sal 
ook die tuislande dan vir Blanke eksploitasie met skađelike gevolge vir die Bantoe oopgestel moet word.

6.3.1.3. Die staat het op vertoë om 'n deurtastende ondersoek na die stelsel te laat instel, geantwoord dat die owerheid trag om die nadele van trekarbeid te bekamp; dat oorwegend jong ongetroude manne in kampongs gevestig word; dat die ooreenkomste met buurstate (Lesotho, Malawië, Mosambiek, e.a.) nie vir gesinsmatige arbeiduitvoer voorsiening maak nie; gesinsmatige trekarbeid kan slegs in die landbousektor plaasvind. ${ }^{28}$

6.3.1.4. Die Sinode van 1975 te Worcester het besoek van dr. B. Naudé van die Christelike Instituut ontvang. Daaroor sowel as oor die formulering van die standpunt oor trekarbeid het volgens persberigte spanning tussen Blanke en Swart afgevaardigdes ontstaan. Sonder enige Skrifverwysing het die moderator trekarbeid as in stryd met die evangelie laat veroordeel. Pogings om meer realisties en genuanseerd te oordeel, is gefnuik en die skriba, ds. Sam Buti, het in neo-imperialistiese kategorië gesê: „Ons swart Suid-Afrikaners, ons word trekarbeiders genoem in ons eie land". ${ }^{24}$

\subsubsection{Swart Afrikaanse arbeiders buite Suid-Afrika.}

6.3.2.1. Verslae van die CCAP Nkhoma, CCAP Salisbury en ARC Rhodesië aan die Federale Raad van die NGK in 1968 vestig almal se aandag op die "family problems" wat uit die stelsel van trekarbeid voortvloei. Selfs in Rhodesië waar die trekarbeider sy familie kan meeneem, verkies hy gewoonlik om hulle in die vertroude landelike omgewing agter te laat.

6.3.2.2. Skynbaar aanvaar die regerings van Malawië en Zambië trekarbeid as gewoon en word in daardie politieke sfere geen drukte oor trekarbeid ondervind nie, behalwe oor praktiese probleme soos Afrikaanstalige dokumente, taalprobleme ens. Selfs kerke agiteer daar skynbaar glad nie teen die stelsel van trekarbeid nie.

6.3.3. Algemene indruk. Die protes teen die voorkoms en stelsel van trekarbeid in Suid-Afrika kom ook nie van die buurstate Lesotho, Swaziland, Botswana, Mosambiek, Rhodesië, Malawië nie. Selfs tuislandregerings het tot nog toe ook weinig geagiteer teen opheffing van die stelsel. Prof. N. C. Manganyi beoog „overhauling of the system in its entirety. What this would mean in politicoeconomic and sociologic terms should be the object of urgent investigation... The first of these that the mining industry should be progressively become home-based in terms of its labour resources". Hy wys trekarbeid af" maar vra ook nog 'n ondersoek na die alternatief.

6.3.4. Opmerking: Daar is dikwels spanning by Swart Afrikane merkbaar en talle druk hulle soms in neo-imperialistiese begrippe oor trekarbeid uit. Tog meen ek dat die meeste Swart outoriteite wat ek kon raadpleeg, soms versigtig en soms meer uitgesproke aansluit by die realiteit van tuislande met hulle bepaalde etniese identiteite, tradisie en kultuur. By hulle is ook begrip vir die mensprobleem voor die ontsaglike opgawe aan die Bantoe om in kort tyd in 'n proses van dekolonialisasie uit sy tradisionele leefwêreld te tree en in eie gebiede en onder eie beheer 'n eie sosio-ekonomies- 
politieke toekoms te floteer. Daar is voor die uitdaging meer inherente verwantskap tussen wit en swart Afrikaanse kerklike as met neo-imperialistiese kerklike standpunte.

\section{Die regering en kerklike standpunte}

Die standpunt, optrede en prognose uit regeringskringe val buite die bestek van hierdie referaat. Daaroor het byvoorbeeld dr. C. J. Jooste in „Die Bantoebevolking in die Blanke gebied" (Sabra-publikasie) gepubliseer.

Adj.-Min. P. G. J. Koornhof het op 24 Julie 1971 te Stellenbosch $^{3}$ gesê dat die Regering die implikasies en gevolge van die stelsel van trekarbeid besef. Verskynsels soos homoseksualiteit en immoraliteit word doelbewus en redelik geslaagd bekamp. Aangesien hoofsaaklik ongetroude mans uit die tuislande gebruik word, word gesinsverbrokkeling teëgewerk. Hy verlang egter morele verantwoording oor vrae soos: Is dit moreel geregverdig om trekarbeid te verbied en buitelandse en binnelandse gesinne alle inkomste te ontneem en hongersnood te veroorsaak? Tans verdien Bantoes sowat $R 1000$ miljoen in Blanke gebiede waarvan 'n redelike deel na die tuislande gaan. Is dit moreel geregverdig dat trekarbeiders as gesinne hierdie hele inkomste in die plek van werk moet bestee? Is dit moreel geregverdig om plaaslike ondernemings van trekarbeid te beroof? Sou sy kritici moreel verlief neem indien instromingsbeheer en trekarbeid afgeskaf word en die immorele, armoedige en ellendige toestande van die eertydse plakkers- en sakdorpe rondom die Blanke stede hom weer gaan herhaal? Is sy kritici bereid om self hulle huis en tuinwerk te doen? „Wat sommige van die pleitbesorgers eintlik graag wil bewerkstellig, is die oorstroming van die Blanke gebied met 'n konglomeraat van lede van die Swartvolkere. As die witman en sy land dan order geploeg is, kan Pan Afrikanisme seëvier om op sy beurt weer die slagoffer van kommunisme en van Rooi China te word..." Indien trekarbeiders ongehinderd mag emigreer, word buurstate, tuislande en volksgemeenskappe „beroof" en die voorsiening van huisvesting, geriewe, skole, ontspanning, dienste ens. 'n onmoontlike taak. Die regering wil deur middel van grensnywerhede ' $n$ doeltreffende vervoerstelsel en ontwikkeling van die tuislande desentraliseer omdat arbeid nie 'n kommoditeit is nie en die mens as Volksmens binne 'n assimileerbare milieu moet werk. Wat doen talle van die felste kritici egter self behalwe om die regering te blameer positief om nyweraars in die mense en in die tuislande te interesseer?

\section{Ten besluite}

8.1. Alle standpunte hou die Regering in Pretoria verantwoordelik vir die stelsel en sy gevolge. Die kerke veroordeel trekarbeid op sterkte van die gesins- en tuislandontwrigtende uitwerking daarvan. Kerke kan geen oplossing uitwerk nie. Die antwoord op hierdie vraagstuk moet van die Regering kom.

8.1.1. Wit en Swart Afrikane vra die Regering om 'n deeglike ondersoek te laat instel en 'n alternatief vir trekarbeid te laat 
ontwerp. Het daar nie weer iets soos 'n Tomlinson-kommissie in hierdie stadium dringend nodig geword nie?

8.1.2. Het die Regering hom al behoorlik verantwoord oor prioriteite? Het die ekonomie of die gemeenskapsontwikkeling, die materiële of menslike sektor, in hierdie kritieke stadium prioriteit? Om te beweer dat die mens nie sonder die ekonomie kan nie, oorvereenvoudig die punt in geding.

8.1.3. Het die Regering hom behoorlik verantwoord oor kommunikasie en koördinasie tussen departemente? Iemand het met verwysing na die tweede Sasol onlangs gevra: Waarom 'n nuwe Swart pool in 'n Blanke gebied skep en mense na die steenkool bring, in plaas van om die steenkool na die mense te bring? Derglike vrae rys ook m.b.t. die hawe by Saldanha op. Is dit werklik vir Kleurlingarbeid bedoel, of word dit ' $n$ pool vir Swart trekarbeid en geleidelike Swart immigrasie? Die kritiek dat ekonomiese determinasie die mens aan 'n onpersoonlike mag onderwerp en daarom verontmens in plaas van dat ekonomiese diensbaar is aan die menslike, moet in duidelike beleid verantwoord word.

8.1.4. Op die drumpel van selfregerende tuislande moet 'n duidelike interstaatlike beleid oor trekarbeid geformuleer word. Die stadium is bereik waar ook die tuislandregering Swart leiers en akademici venoot in die soeke na ' $n$ oplossing en beleidformulering moet word.

8.1.5. Die stelling dat trekarbeid 'n „oorgangsfase" verteenwoordig word betwyfel. In sy intreerede in die departement regte aan UP het prof. S. R. van Jaarsveld onlangs gepleit vir groter „realisme" deur in die proses van tuislandkonsolidasie die land van die werker nader aan die stede in plaas van die werker na grond ver van die werksplek te bring. Die Regering moet hom verantwoord omdat juis trekarbeid twyfel oor die morele regverdiging van die beleid van veelvolkige ontwikkeling laat opkom. Sommige twyfel omdat hulle trekarbeid in permanente diens van die beleid beskou. Ander twyfel omdat hulle in die toenemende trekarbeid die mislukking van die beleid gewaar.

8.2. Volledigheidshalwe moet daar ook gelet word op die voordele van trekarbeid. Enersyds het P. D. Banghart aangetoon dat die Bantoe eenvoudig anders as ' $n$ Blanke onder die stelsel van trekarbeid reageer. Die feit dat die gesins- en huweliksverhouding by die Bantoe op minder emosionele betrokkenheid berus, veroorsaak dat trekarbeid nie so 'n ontwrigtende uitwerking het as wat onder Blankes die geval sou gewees het nie. ${ }^{30}$ Kerklike standpunte rig hulle feitlik uitsluitlik op die gevolge vir die getroude trekarbeider, terwyl argumenteer kan word dat by Bantoegemeenskappe behoefte bestaan dat die ongetroude adolessent deur trekarbeid sy horison moet verruim om sy gemeenskap in die stroomversnelling van verandering beter te kan dien. Indien hierdie argument opgaan, moet meer genuanseerd geoordeel word as wat die NGKA in 1975 gedoen het. Is daar wesenlik soveel beswaar dat jong ongetroude mans soos dienspligtiges, matrose of studente vir periodes in koshuise of kampongs gevestig word? Kan die opbrengs van 'n stewige belasting vir elke trekarbeider op werkgewers wat progressief verhoog word 
volgens ouderdom van die arbeiders nie inderdaad aangewend word om groeipunte in die tuistes te stimuleer nie?

8.3. Verantwoord plaaslike owerhede hulle voldoende en beskik hulle oor die magte om te beslis wanneer aansoeke om industriële of nywerheidsontwikkeling dien op die vraag of plaaslik voldoende arbeid aanwesig is? Word ontwikkeling wat op trekarbeid aangewys is radikaal in die lig van arbeidtekort afgewys?

8.4. Kritici van die stelsel hou naas die sentrale owerheid veral werkgewers verantwoordelik om behoorlike gesinshuisvesting, geriewe, ontspanning, wedersydse familiebesoek, ens., moontlik te maak. Die nyweraar behoort hom ook sterker en oor lang termyn te verantwoord of hy nie ook groter prioriteit aan die menslike faktor moet gee en sy onderneming na die mense in plaas van mense na sy onderneming bring nie.

8.5. Die mees voor die hand liggende alternatief teenoor trekarbeid is grensgebied- en tuisland-ontwikkeling op landbou, industriële, nywerheids en myngebiede. Daarmee saam ontwikkel die infrastruktuur. Hiervoor is primêr motivering en sekondêr verantwoordelike uitvoering nodig. Op hierdie roeping moet elke tuisland- en stamowerheid hom verantwoord. Die tuisland-, stam- en familie-owerhede gee immers toestemming tot trekarbeid. Trekarbeid is in wese 'n simptoom dat daar in die tuisland en onder sy mense ekonomies iets haper wat heel moontlik met die houding en instelling van die mense verband hou. Geen Blanke owerheid of nyweraar kan hierdie wortel raak nie.

8.6. Menswees vereis primêr verantwoordelike keuses van elke trekarbeider. Sy problematiek hou verband met sy hele eksistensie en keuses wat sy stam, familie, gesin en hyself uitoefen. Trekarbeid hang gevolglik ten nouste saam met verantwoording ten opsigte van ouerskap, gesinsbeplanning, motivering, opvoeding, opleiding, geleenthede, ens. Die Bantoe moet bevry word van die eensydige akkulturasie met die Westerse geldekonomie, waaronder hy geld die allesbeheersende faktor in sy lewe maak - terwyl Blankes daarnaas 'n hele sisteem geestelike en kulturele waardes koester. Die toekoms verg ook van elke Swart man verantwoording aan die norme wat sy hele mens-wees omvat.

8.7. Die verantwoordelikheid van die trekarbeider, sy gesin, stam en tuislandowerheid is in die meeste kerklike standpunte tot nog toe onderbeklemtoon, waarskynlik omdat die lang periode van kolonialisme met sy idee van ,voogdyskap" die verantwoordelikheid eensydig op Blanke instansies geplaas het. Hierdie onderbeligte faset is egter logies die primêre wat prioriteit verg.

8.8. Die aandag vir die gesin as bepalende faktor vir die menswees van die enkeling, die welvaart van die gemeenskap en vir vreedsame naasbestaan met ander verdoem die stelsel van trekarbeid vir getroude persone. Juis die aandag vir die gesin en die mens-in-gesin verdoem egter ook die neo-imperialistiese oplossing wat ervaring uit homogene Europese gemeenskappe net so op heterogene werklikhede in Suid-Afrika wil toepas. Wit en Swart Afrikane (en nie Europeërs uit liberale of sosialistiese hoek nie) moet in ontspanne 
koöperasie en nugter realiteitsbesef die mensprobleem (houding, motivering, etiek, betrokkenheid, idealisme en roepingsbewustheid) agter die trekarbeid aanpak en so die uitdaging van die toekoms met 'n wil om te slaag tegemoet tree.

(Referaat gelewer deur prof. B. Spoelstra tydens Sabra se Dagkonferensie oor Die Kerk en Rasseverhoudinge in Durban op 5 Maart 1976. Vgl. Tydskrif vir Rasse-aangeleenthede, April 1976, Vol. 27, Nr. 2.)

1 Die outeur erken met dank hulp van dr. C. J. Jooste en mnr. S. L. Strydom van Sabra wat behulpsaam was om inligting te bekom.

2 Skeen, S. O. en Rust, H. A.: Trekarbeid en Kerk, 1971.

3 Koornhof, Adj.-Min. P. G. J.: Die Morele aspekte van Trekarbeid voor ASVG te Stellenbosch, 1971.

4 Möller, H. J.: Cultural and religious implications of migratory labour. Umpumulo 1970. Vgl. ook samevattende definisie, p. 172.

5 Wellmer, G.: Mission and Migrant Labour. AIM, Jan Smuts 1976. Vgl. ook Koornhof, P. G.: T.a.p.

6 Möller: T.a.p.; St. John White: T.a.p.; Landmanverslag: Ras, volk en nasie en volkereverhoudinge in die lig van die Skrif.

7 Koornhof, P. G.: T.a.p.; Skeen, S. O. en Rust, H. A. T.a.p.; Wilson, F.: Economics of Migrant Labour en S.A. Umpumulo 1970. Kotzé, D. A.: Naturelle-arbeid as beleidsbepalende faktor en S.A. TRA 14 (4), 1963, p. 264 e.v.

8 Rhoodie, N. J.: Sosiologiese probleme wat gepaard gaan met die gebruik van Bantoe-arbeid in Blanke gebiede. TRA, 16 (3), 1965, p. 142 e.v.

9 Vgl. Koornhof; T.a.p.; Möller: T.a.p.; Skeen en Rust: T.a.p.

10 St. John White, D.: Biblical on Social perspectives. Source Document, AIM, Jan Smuts, 1976.

11 Prof. Manganyi, N. C.: Reassesment towards a new consensus on Migratory Mine Labour. Jan Smuts MIK, 1976.

12 Möller: T.a.p.; St. John White: T.a.p.; Landmanverslag: Ras, Volk en Nasie en Volkereverhoudinge in die lig van die Skrif. Verslag van die Algemene Sinode NGKSA, 1974.

13 D. A. Kotze: T.a.p., p. 274.

14 E. Bruwer: T.a.p., p. 166. Vgl. ook Möller: T.a.p., p. 88, 92.

15 Umpumulo 1970. Missiological Institute: Migrant Labour and Church Involvement, p. 170 e.v.

16 B. Spoelstra: Kolonialisme en ons Sendingkrisis gedurende die vorige eeu (L. Floor (red.): Die Saailand is die wêreld, jubileum-uitgawe Hammanskraalse Teol. Skool, 1972, p. 151-192).

17 Vgl. ELK Sinode, 1970.

18 Voipio R.: A Review of work done by S.A. churches. Umpumulo, 1970; Kritzinger, J. J.: Sending en Kerk en S.W.A., Vol. I, p. 407 e.v.

19 Tute, D.: The Migratory Labour System: The Role of the Church. MIK, Jan Smuts, 1976.

20 Synott, F.: Adaptation of the Churche's Mission to the Migrant Labour Situation. Umpumulo 1970, p. 147 e.v.

21 Van Heerden, C. I.: Bywoning van Samespreking oor Trekarbeid te Umpumulo. Evaluering .... bl. 33. F. J. van Wyk: Summary and Evaluation of today's situation regarding the system of migrant labour. Umpumulo, 


\section{In die Skriflig}

1970, bl. 112. Vgl. hierdie aanhaling ook as bewys en illustrasie by my voorgaande paragraaf 6.1.1.

22 Van Heerden: T.a.p., p. 34; Jooste, C. J.: Policy and Legislation concerning Migrant Labour. Umpumulo 1970, bl. 57 e.v.

23 S.A. Outlook, Feb. 1974.

24 Rapport 8.6.75; Die Burger 7.6.75.

25 Slegs twee Afrikaanse kerke het aan die konferensie te Umpumulo in 1970 deelgeneem, nl. NGKSA en GKSA. Dit is ook die enigste twee van wie daar offisiële standpunte oor trekarbeid bekom is.

26 Verslag voorgele aan die Sinode NGK in Kaapland 1965; Voorlegging aan Alg. Sinode van die NGK, Bloemfontein 1966, Studiestukke oor Rasseaangeleenthede; Verslae aan die Federale Raad van N.G. Kerke, 1968; Besluite van die Algemene Sinode NGK, 1970.

27 Die Transvaler 16.1.73.

28 Skrywe Adm. Sekr., minister van Bantoeadministrasie, p/a ds. Malan.

29 Mohlabi, F. R.: Moral Effects of the System of Migratory Labour on the labourer and his family. Umpumulo, 1970, bl. 73-80.

30 Banghart, P. D.: The Effects of Migrant Labour on the social structure of the Bantu Homelands. Umpumulo, 1970, p. 95 e.v.; vgl. ook Rhoodie: T.a.p., p. 142. 